\title{
Dietary Selection by Goats and Sheep in a Deciduous Wood- land of Northeastern Brazil
}

\author{
JAMES A. PFISTER AND JOHN C. MALECHEK
}

\begin{abstract}
The dietary botanical composition of indigenous sheep and goats was determined in the semiarid tropics of northeastern Brazil, using esophageally fistulated animals. Sheep and goats selected similar diets during the dry season (May-Dec.). Main dietary components for both species were dried forbs and browse. Leaf litter from the deciduous trees provided the majority of dry season forage (500-1,500 kg/ha) and was a crucial element of dry season diets (20-70\%). During the wet season (Jan.-Apr.), sheep selected mainly grasses and forbs, while goats rapidly shifted among grasses, forbs, and browse. By displaying attributes of both browsers and grazers, neither sheep nor goats conformed to traditionally rigid characterization. We found no indication that goats are better adapted for survival in this tropical environment than are sheep because of the botanical composition of their diets. Management implications of this study for the caatinga vegetation zone are discussed.
\end{abstract}

Although range science literature is replete with studies reporting detailed data on diets of cattle and sheep, few investigations have examined diets of goats grazing alone, or in common with other livestock (Malechek and Provenza 1983). Van Dyne et al. (1980) catalogued studies of livestock diets, and noted 5 and 38 such studies for goats and sheep, respectively. Only 3 studies listed in this paper compared dietary selections by goats and sheep grazing together on common ranges. No work has been done using esophageally fistulated animals to examine diets of either goats (Capra hircus) or sheep (Ovis aries) in northeastern Brazil.

Generally comparisons of the dietary selections of goats have been made with sheep of European origin. Little information is currently available on selectivity of tropical hair sheep or goats.

At the time of this research, authors were graduate research assistant and professor, respectively, Department of Range Science, Utah State University, Logan Utah, 84322. J. Pfister is presently research scientist, Department of Kange and Wildlife Management, Texas Tech University, Lubbock 79409.

Research was financed by USAID Grant No. AID/DSAN/XII-G-0049 as part of the Small Ruminant Collaborative Research Support Program in cooperation with Empresa Brasileira de Pesquisa Agropecuaria.

The authors wish to thank the personnel of the Centro National de Pesquisa de Caprinos for provision of physical facilities and assistance during the study. We are especially grateful to Venceslau Alves Costa, Animal Husbandryman, for his assistance. Manuscript preparation supported by Texas Tech University.

Manuscript accepted 25 April 1985.
Goats have acquired a reputation for survivability on harsh, degraded rangeland (Devendra 1978). This may be due, in part, to unique dietary selections made by goats (McCammon-Feldman et al. 1981). French (1970) maintained that high survivability by goats was related to their relatively unspecialized feeding habits. Increased specialization implies fewer plant species or parts eaten. Observations have indicated that goats eat a wider array of plant species than do other livestock (French 1970, Wilson et al. 1975).

Conversely, Van Soest $(1980,1982)$ stated that goats should display more specialized feeding habits than do sheep, based on body size, gastrointestinal capacity, nutrient requirements, and feeding strategy. He classified goats and sheep in 2 ways. First, goats are classified as forb- or browse- preferring intermediate (between browsers and grazers) feeders, and sheep as grasspreferring intermediate feeders. Van Soest's (1982:7) second classification lists goats as intermedite browsers, and sheep as grazers.

Livestock producers in northeastern Brazil prefer to raise sheep over goats (Gutierrez et al. 1981) because of many complex socioeconomic factors (Primov 1982). For instance, sheep do not require the less penetrable, more expensive fencing required for goats, especially adjacent to cropland. On the other hand, goats are often viewed by Brazilian producers as a form of drought insurance because of their reputed survivability and minimal requirements for supplemental feeds during droughts.

The objectives of this study were to determine the botanical composition of goat and sheep diets on a seasonal basis, and to evaluate the selective feeding strategies of goats and sheep. Such information would provide a basis for more sophisticated management and insight into the question of comparative adaptability of the 2 species.

\section{Study Area}

The 40-ha study area was situated on the Brazilian National Goat Research Center (CNPC), $10 \mathrm{~km}$ from Sobral, Ceara' state, Brazil. Sobral is located at $3.42^{\circ}$ south latitude, $40.21^{\circ}$ west longitude, at an elevation of $63 \mathrm{~m}$. The landscape in the study area is slightly undulating. Soils are generally eroded, shallow clays (45$130 \mathrm{~cm}$ ), underlain with crystalline bedrock.

\section{Climate}

The climate in the Northeast is characterized by distinct wet and 
dry seasons. The dry season typically extends from June to December, although periodic droughts may extend the dry season to 11 months. The wet season usually extends from January through May. Periodic droughts are characteristic of this region (Freise 1938, Trewartha 1981).

The 30-year average precipitation in Sobral, and precipitation for 1981 and 1982 are 759,538 , and $650 \mathrm{~mm}$, respectively. Variability in the annual amount, as well as the spatial and temporal distribution of moisture, is extreme (Freise 1938). Temperatures are hot, exceeding $32^{\circ} \mathrm{C}$ almost every day, with little seasonal variation.

\section{Vegetation}

The vegetation of this region is called caatinga, an Indian word meaning white forest (Ferri 1980), so-called because the deciduous woodlands have a whitish aspect during the dry season. Caatinga vegetation is not homogenous, but is a complex mix of deciduous trees and shrubs with an annual herbaceous understory (Ferri 1980, Pfister et al. 1983). The caatinga is noted for its density, diversity, and absence of perennial grass cover (Eiten and Goodland 1979).

The 40-ha pasture used in this study supported a stand of caatinga vegetation. These woodlands are areas of second or third growth that have not been recently cleared (i.e., within 20 to 40 years). Principal tree species on the study area are pau branco (Auxemma oncocalyx Taub.), sabia' (Mimosa caesalpiniaefolia Benth.) catinguera (Caesalpinia pyramidalis Benth.), marmeleiro (Croton hemiargyreus Muell. Clrg.), mororo' (Bauhinia forficata Link), and mofumbo (Combretum leprosum Mart.). Important annual herbaceous plants include Hyptis spp., Bainvillea spp., Phaseolus spp., and jitirana (Ipomoea spp.), a climbing vine. Dominant annual grasses are Paspalum spp., and Panicum spp., with numerous other genera represented (Pfister et al. 1983). The taxonomical classification of many plant species in this area has not been completed.

\section{Methods}

The native hair sheep and SRD (Sem Raca definida- without definite race) goats used in this study were about 2 years old and weighed about $18 \mathrm{~kg}$ when the sampling began. At approximately monthly intervals, 6 to 8 esophageally fistulated sheep or goats were used to collect diet samples in the 40 -ha pasture. The 30 min. collections were done at $0530 \mathrm{hr}$ for 3 consecutive days.

Extrusa samples obtained from fistulated animals were mixed and divided into 2 portions. One portion was frozen at $-17^{\circ} \mathrm{C}$, and the other dried at $40^{\circ} \mathrm{C}$ for 3 days. The latter was used for botanical determinations after pooling sub-samples over the $\mathbf{3}$ days for each individual animal.

Botanical composition was determined by the microscope point method of Harker et al. (1964). Plant tissue was systematically identified at 200 points per sample at $15 \mathrm{x}$. Plants were identified by species, as leaf or stem, fruit or flower, or as unidentifiable.

Forage availability (kg/ha) was estimated by hand-harvesting all herbaceous vegetation within $30-40,0.5 \mathrm{~m} \times 0.6 \mathrm{~m}$ randomly placed quadrats. Leaf litter was estimated by collecting dried leaves from these same quadrats. Tree foliage was estimated by stripping all leaves to a browsing height of $1.6 \mathrm{~m}$ from a sample population of the 4 major tree species: pau branco, sabia', catingueira, and mororo'. These 4 species were initially thought to be the only trees acceptable to livestock. Thirty individual trees of each species were randomly selected and stripped during each sampling period (except during September). Tree density was determined by counting individuals in 30 randomly placed $4 \mathrm{~m} \times 10 \mathrm{~m}$ plots, and availability of browse forage was calculated by multiplying the unit foliage per tree by the density estimate.

Data analysis was done using the statistical package Rummage (Bryce et al. 1980). The experimental design was a split-plot design with repeated measurements comparing sheep and goats, with individual animals nested (Gill 1978:203). Repeated measurements in 1981 were made during May 26-28, June 17-19, July 21-23, August 17-19, September 4-6, October 28-30, and December 14-16. Collection periods in 1982 were January 6-8, February 17-19, and April 26-28. Least squares analysis of variance was used for statistical analysis, with the protected LSD procedure used to compare individual means.

\section{Results}

\section{Forage Availability}

Leaf litter was clearly the dominant component of the available forage in the dry season (July-Dec., 1981) (Fig. 1). Peak amounts of leaf litter $(1,500 \mathrm{~kg} / \mathrm{ha})$ were recorded in August. In October and December about $500 \mathrm{~kg} / \mathrm{ha}$ of leaf litter was recorded. Herbaceous material and tree foliage contributed relatively little to the available forage after the early dry season (May-July).

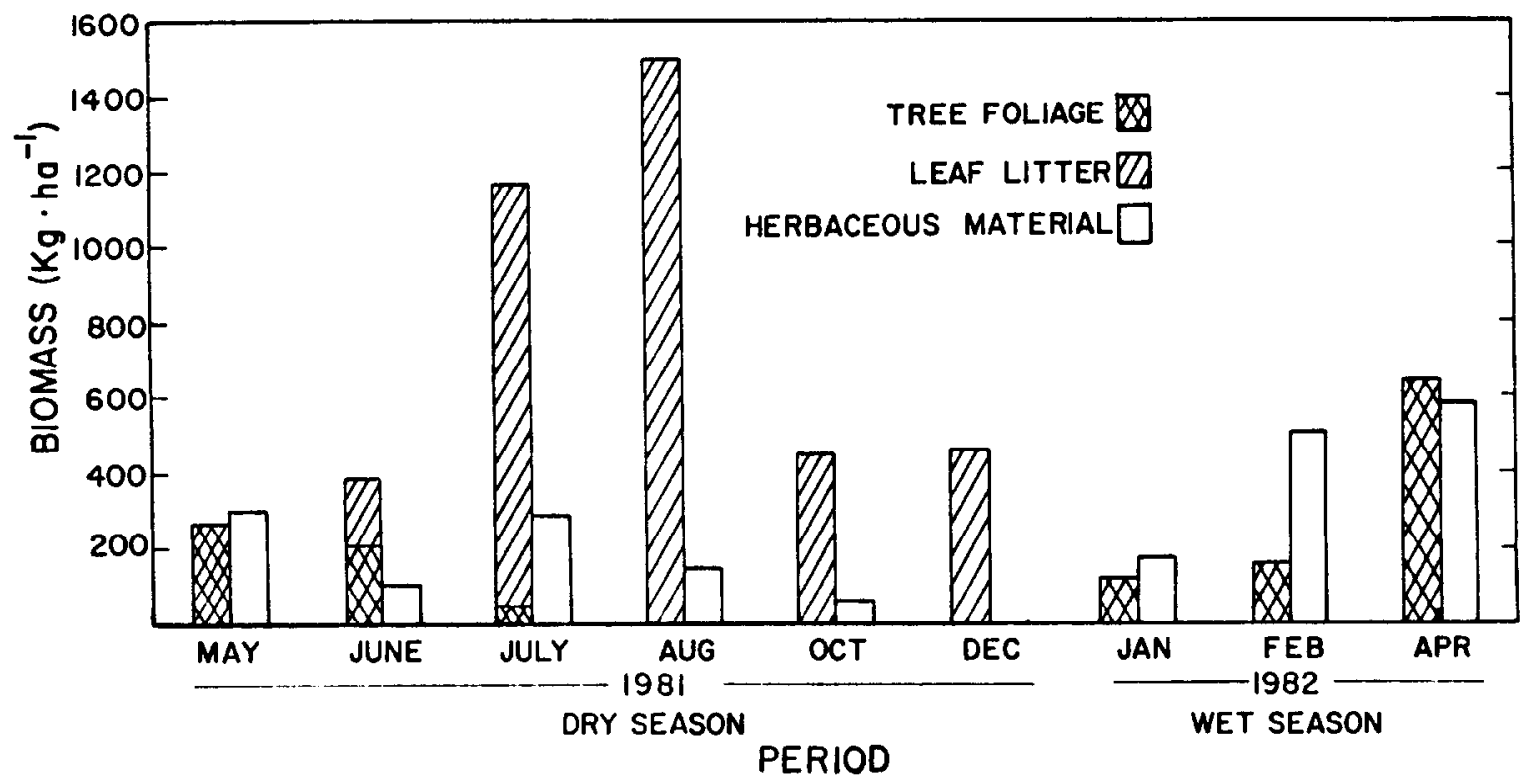

Fig. 1. Biomass $(\mathrm{kg} / \mathrm{ha})$ of available forage during 10 sample periods, 1981 and 1982. 
Table 1. Mean botanical composition (\% and standard deviation) of goats'and sheep diets during 10 sample periods, 1981 and 1982 in northeastern Brazil.

\begin{tabular}{|c|c|c|c|c|c|c|c|c|c|c|}
\hline & \multicolumn{2}{|c|}{ May } & \multicolumn{2}{|c|}{ June } & \multicolumn{2}{|c|}{ July } & \multicolumn{2}{|c|}{ August } & \multicolumn{2}{|c|}{ September } \\
\hline & sheep & goats & sheep & goats & sheep & goats & sheep & goats & sheep & goats \\
\hline $\begin{array}{l}\text { Forbs } \\
\text { Jitirana (Ipomoea spp.) } \\
\text { Paco-Paco (Wissadula spp.) } \\
\text { Bambural branco (Bainvillea spp.) } \\
\text { Bambural verdadeiro (Hyptis spp.) } \\
\text { Bambural russarente (unclassified) } \\
\text { Mariana (Commelina spp.) } \\
\text { Other forbs } \\
\text { Total forbs }\end{array}$ & $\begin{array}{r}43.6(9.8) \\
0.0 \\
0.0 \\
1.8(1.8) \\
0.0 \\
18.1(8.0) \\
8.8(1.7) \\
72.3(7.0)\end{array}$ & $\begin{array}{c}71.5(17.8) \\
0.0 \\
0.0 \\
1.6(3.9) \\
0.0 \\
0.0 \\
3.8(2.4) \\
76.9(14.8)\end{array}$ & $\begin{array}{c}9.6(6.7) \\
2.2(5.9) \\
0.0 \\
0.3(0.7) \\
0.0 \\
18.0(13.6) \\
8.8(7.3) \\
38.9(18.4)\end{array}$ & $\begin{array}{l}21.3(15.2) \\
0.0 \\
0.0 \\
0.0 \\
0.0 \\
3.1(4.3) \\
3.9(4.2) \\
28.3(20.6)\end{array}$ & $\begin{array}{c}32.9(11.1) \\
4.2(3.9) \\
0.4(0.5) \\
0.0 \\
0.0 \\
0.4(0.6) \\
0.1(0.2) \\
38.0(12.0)\end{array}$ & $\begin{array}{c}71.6(9.4) \\
2.0(1.1) \\
0.9(1.2) \\
0.0 \\
0.0 \\
0.3(0.7) \\
0.5(1.1) \\
75.3(9.6)\end{array}$ & $\begin{aligned} & 58.6(9.4) \\
& 2.3(3.6) \\
& 2.8(2.5) \\
& 0.3(0.6) \\
& 0.0 \\
& 0.8(0.9) \\
& 7.0(3.5) \\
& 71.8(9.7)\end{aligned}$ & $\begin{array}{r}55.1(19.7) \\
6.1(7.2) \\
3.2(3.4) \\
1.0(1.0) \\
0.0 \\
0.8(1.5) \\
4.4(3.2) \\
70.6(22.0)\end{array}$ & $\begin{aligned} & 21.4(4.5) \\
& 0.0 \\
& 1.1(1.7) \\
& 1.4(1.7) \\
& 0.0 \\
& 0.0 \\
& 2.3(2.5) \\
& 26.2(2.6)\end{aligned}$ & $\begin{array}{l}32.4(16.9) \\
0.0 \\
7.6(15.9) \\
0.0 \\
0.0 \\
0.0 \\
0.4(1.1) \\
40.4(19.8)\end{array}$ \\
\hline $\begin{array}{l}\text { Browse } \\
\text { Mororo' (Bauhinia forficata) } \\
\text { Sabia' (Mimosa caesalpiniaefolia) } \\
\text { Catingueira (Caesalpinia pyramidalis) } \\
\text { Marmeleiro (Croton hemiargyreus) } \\
\text { Mofumbo (Combretum leprosum) } \\
\text { Melosa (Ruellia asperula) } \\
\text { Pau branco (Auxemma oncocalyx) } \\
\text { Other browse } \\
\text { Total browse }\end{array}$ & $\begin{array}{l}7.4(4.2) \\
8.6(6.1) \\
0.3(0.7) \\
0.0 \\
0.1(0.4) \\
0.0 \\
0.4(1.6) \\
1.8(2.3) \\
19.7(8.4)\end{array}$ & $\begin{array}{l}5.5(5.2) \\
12.4(12.9) \\
0.0 \\
0.0 \\
1.3(3.2) \\
0.9(2.1) \\
0.6(1.8) \\
1.6(1.0) \\
22.3(15.0)\end{array}$ & $\begin{array}{r}21.4(11.6) \\
10.3(10.6) \\
0.4(0.8) \\
0.2(0.7) \\
0.2(0.4) \\
10.2(9.1) \\
0.0 \\
6.3(2.1) \\
49.0(20.1)\end{array}$ & $\begin{array}{l}42.6(19.9) \\
14.6(16.6) \\
0.0 \\
0.0 \\
0.1(0.3) \\
5.4(6.7) \\
0.0 \\
5.6(3.2) \\
68.3(23.4)\end{array}$ & $\begin{array}{l}48.9(12.6) \\
5.1(1.2) \\
0.8(0.9) \\
0.0 \\
0.3(0.6) \\
0.3(0.4) \\
0.2(0.4) \\
0.0 \\
55.6(13.4)\end{array}$ & $\begin{array}{r}9.4(6.1) \\
2.6(1.9) \\
3.1(6.3) \\
0.0 \\
1.1(1.7) \\
0.4(1.0) \\
0.1(0.4) \\
3.7(2.6) \\
20.4(9.7)\end{array}$ & $\begin{array}{r}14.6(6.9) \\
3.7(2.8) \\
1.3(1.1) \\
1.0(1.4) \\
0.1(0.2) \\
0.3(0.5) \\
0.1(0.4) \\
0.4(0.5) \\
21.5(9.2)\end{array}$ & $\begin{array}{r}22.6(22.1) \\
1.4(1.0) \\
0.5(0.6) \\
0.9(2.3) \\
0.7(1.5) \\
0.0 \\
0.1(0.2) \\
0.9(1.2) \\
27.1(21.6)\end{array}$ & $\begin{array}{r}31.4(5.9) \\
8.0(3.4) \\
5.1(1.9) \\
18.3(5.3) \\
1.4(0.7) \\
1.0(0.5) \\
1.5(1.4) \\
1.4(1.7) \\
68.1(4.9)\end{array}$ & $\begin{array}{r}15.5(10.7) \\
8.9(9.7) \\
4.8(4.5) \\
13.8(9.4) \\
0.7(1.07) \\
1.5(2.3) \\
1.0(0.9) \\
2.5(1.8) \\
48.7(18.1)\end{array}$ \\
\hline Total grass & $8.1(7.9)$ & $0.4(0.7)$ & $10.2(7.6)$ & $1.1(2.3)$ & $2.1(1.6)$ & $0.3(0.5)$ & $3.6(1.7)$ & $0.1(0.2)$ & $1.9(2.2)$ & $0.6(1.0)$ \\
\hline Unidentifiable & $1.1(1.1)$ & $0.5(0.5)$ & $1.7(1.4)$ & $1.3(2.4)$ & $4.3(3.9)$ & $4.1(1.8)$ & $3.2(2.6)$ & $2.1(1.5)$ & $4.8(3.7)$ & $10.3(8.0)$ \\
\hline Leaf;stem ratio & 2.9 & 2.9 & 7.1 & 11.2 & 8.2 & 4.0 & 2.8 & 3.1 & 5.0 & 3.0 \\
\hline & \multicolumn{2}{|c|}{ October } & \multicolumn{2}{|c|}{ December } & \multicolumn{2}{|c|}{ January } & \multicolumn{2}{|c|}{ February } & \multicolumn{2}{|c|}{ April } \\
\hline & sheep & goats & sheep & goats & sheep & goats & sheep & goats & sheep & goats \\
\hline $\begin{array}{l}\text { Forbs } \\
\text { Jitirana (Ipomoea spp.) } \\
\text { Paco-Paco (Wissadula spp.) } \\
\text { Bambural branco (Bainvillea spp.) } \\
\text { Bambural verdaderio (Hyptis spp.) } \\
\text { Bambural russarente (unclassified) } \\
\text { Mariana (Commelina spp.) } \\
\text { Other forbs } \\
\text { Total forbs }\end{array}$ & $\begin{array}{c}16.3(10.2) \\
0.0 \\
0.3(0.5) \\
0.1(0.2) \\
0.0 \\
2.0(1.7) \\
0.6(0.6) \\
19.3(10.8)\end{array}$ & $\begin{array}{l}23.2(11.7) \\
0.0 \\
0.1(0.2) \\
0.0 \\
0.0 \\
0.6(0.7) \\
0.4(0.6) \\
24.3(11.4)\end{array}$ & $\begin{array}{r}17.6(5.49) \\
0.0 \\
0.2(0.3) \\
0.2(0.3) \\
0.0 \\
0.8(1.4) \\
0.1(0.2) \\
18.9(6.2)\end{array}$ & $\begin{array}{l}21.9(14.4) \\
0.0 \\
0.1(0.2) \\
0.3(0.6) \\
0.0 \\
0.0 \\
0.1(0.2) \\
22.4(14.2)\end{array}$ & $\begin{array}{c}21.0(10.9) \\
0.5(0.7) \\
8.0(5.6) \\
0.0 \\
0.0 \\
9.5(5.5) \\
16.1(8.7) \\
55.1(5.6)\end{array}$ & $\begin{array}{l}9.9(11.8) \\
0.0 \\
1.4(2.0) \\
0.0 \\
0.0 \\
0.8(2.1) \\
12.4(4.6) \\
24.5(16.3)\end{array}$ & $\begin{array}{r}2.9(3.0) \\
0.1(0.3) \\
1.4(1.7) \\
2.0(4.2) \\
28.4(13.9) \\
5.6(6.2) \\
4.8(3.2) \\
45.2(21.7)\end{array}$ & $\begin{array}{r}9.8(5.9) \\
0.5(1.4) \\
0.6(1.4) \\
0.5(1.0) \\
13.6(7.9) \\
0.6(1.4) \\
9.0(3.7) \\
34.6(12.4)\end{array}$ & $\begin{array}{r}2.1(2.3) \\
10.5(10.2) \\
4.8(4.8) \\
0.8(1.2) \\
0.0 \\
1.3(1.2) \\
10.4(3.9) \\
29.9(8.7)\end{array}$ & $\begin{array}{r}3.8(3.9) \\
8.3(8.1) \\
25.8(21.7) \\
4.4(2.9) \\
0.4(1.1) \\
0.0 \\
6.6(3.5) \\
49.3(18.9)\end{array}$ \\
\hline $\begin{array}{l}\text { Browse } \\
\text { Mororo' (Bauhinia forficata) } \\
\text { Sabia' (Mimosa caesalpiniaefolia) } \\
\text { Catingueira (Caesalpinia pyramidalis) } \\
\text { Marmeleiro (Croton hemiargyreus) } \\
\text { Mofumbo (Combretum leprosum) } \\
\text { Melosa (Ruellia asperula) } \\
\text { Pau branco (Auxemma oncocalyx) } \\
\text { Other browse } \\
\text { Total browse }\end{array}$ & $\begin{array}{r}3.0(2.1) \\
12.0(5.9) \\
27.8(14.3) \\
3.8(3.2) \\
0.6(1.6) \\
3.9(7.7) \\
1.0(1.4) \\
1.2(1.3) \\
52.3(14.9)\end{array}$ & $\begin{array}{r}10.2(12.6) \\
12.0(5.6) \\
22.1(12.9) \\
8.9(1.4) \\
0.3(0.4) \\
2.0(1.8) \\
1.8(1.8) \\
1.9(2.1) \\
59.2(13.6)\end{array}$ & $\begin{aligned} & 5.8(2.8) \\
& 7.5(2.3) \\
& 38.1(7.6) \\
& 7.8(3.6) \\
& 0.6(1.0) \\
& 1.4(1.2) \\
& 0.1(0.3) \\
& 3.7(2.1) \\
& 65.0(7.3)\end{aligned}$ & $\begin{array}{r}17.9(17.0) \\
7.3(7.0) \\
22.3(8.9) \\
12.8(7.8) \\
0.3(0.4) \\
3.6(3.8) \\
0.1(0.2) \\
3.4(3.0) \\
67.7(15.0)\end{array}$ & $\begin{array}{l}4.0(2.6) \\
1.0(1.0) \\
0.6(1.0) \\
0.0 \\
0.0 \\
1.4(2.2) \\
0.0 \\
3.4(3.8) \\
10.4(4.6)\end{array}$ & $\begin{array}{c}34.0(18.3) \\
22.6(11.7) \\
5.6(7.6) \\
0.0 \\
0.0 \\
1.4(2.0) \\
0.0 \\
3.5(4.1) \\
67.1(17.1)\end{array}$ & $\begin{array}{l}0.1(0.3) \\
0.5(1.1) \\
0.0 \\
0.0 \\
0.0 \\
1.1(1.8) \\
0.1(0.3) \\
0.3(0.4) \\
2.1(2.0)\end{array}$ & $\begin{array}{l}4.4(3.6) \\
9.5(10.1) \\
0.0 \\
0.0 \\
0.0 \\
8.0(5.6) \\
0.4(0.7) \\
4.5(3.2) \\
26.8(14.2)\end{array}$ & $\begin{array}{r}2.1(4.1) \\
1.0(1.3) \\
0.0 \\
0.0 \\
1.4(1.7) \\
44.1(8.1) \\
1.8(1.8) \\
7.1(4.6) \\
57.5(8.9)\end{array}$ & $\begin{array}{c}6.5(7.9) \\
12.0(10.4) \\
0.0 \\
0.0 \\
12.8(6.7) \\
1.9(2.2) \\
1.8(3.4) \\
10.8(5.0) \\
45.8(18.0)\end{array}$ \\
\hline Total grass & $13.0(11.4)$ & $2.1(1.2)$ & $7.1(3.8)$ & $1.8(1.7)$ & $33.4(6.7)$ & $6.1(6.9)$ & $51.9(23.4)$ & $37.9(13.2)$ & $11.1(9.6)$ & $2.5(3.2)$ \\
\hline Unidentifiable & $14.5(5.8)$ & $14.4(4.4)$ & $9.0(3.5)$ & $8.3(6.1)$ & $0.9(1.5)$ & $2.4(2.8)$ & $0.9(0.8)$ & $0.8(0.7)$ & $1.6(1.1)$ & $2.8(2.4)$ \\
\hline Leaf:stem ratio & 2.4 & 2.5 & 3.1 & 3.2 & 2.9 & 7.3 & 5.5 & 4.6 & 2.7 & 3.8 \\
\hline
\end{tabular}

The amount of forage available in the wet season showed a steady increase with forage maturation. Herbaceous annuals responded more quickly to precipitation than did the trees, increasing from January $(1,976 \mathrm{~kg} / \mathrm{ha})$ to February $(587 \mathrm{~kg} / \mathrm{ha})$. From February to April the biomass of tree foliage increased from about $160 \mathrm{~kg} / \mathrm{ha}$ to $650 \mathrm{~kg} / \mathrm{ha}$.

\section{Dietary Selection.}

Both sheep and goats selected large but variable amounts of standing dead forb material and browse during the early dry season (May-Aug.). Two important species were jitirana, a climbing vine, and mororo', a leguminous tree (Table 1).

Relative amounts of leaf and stem consumed were highly variable during the May to August period (Table 1). There was a significant $(\mathrm{P}=.014)$ period by species interaction for leaf:stem ratios over all periods, and significant period by animal species interactions for browse, grass, and forbs in animal diets, reflecting seasonal fluctuations in selectivity. However, only for the amount of grass in diets was there a significant $(P<0.01)$ difference between animal species.

Diets of goats and sheep were similar during the late dry season period (Sep.-Dec.). The leaves of several tree species (catingueira, 


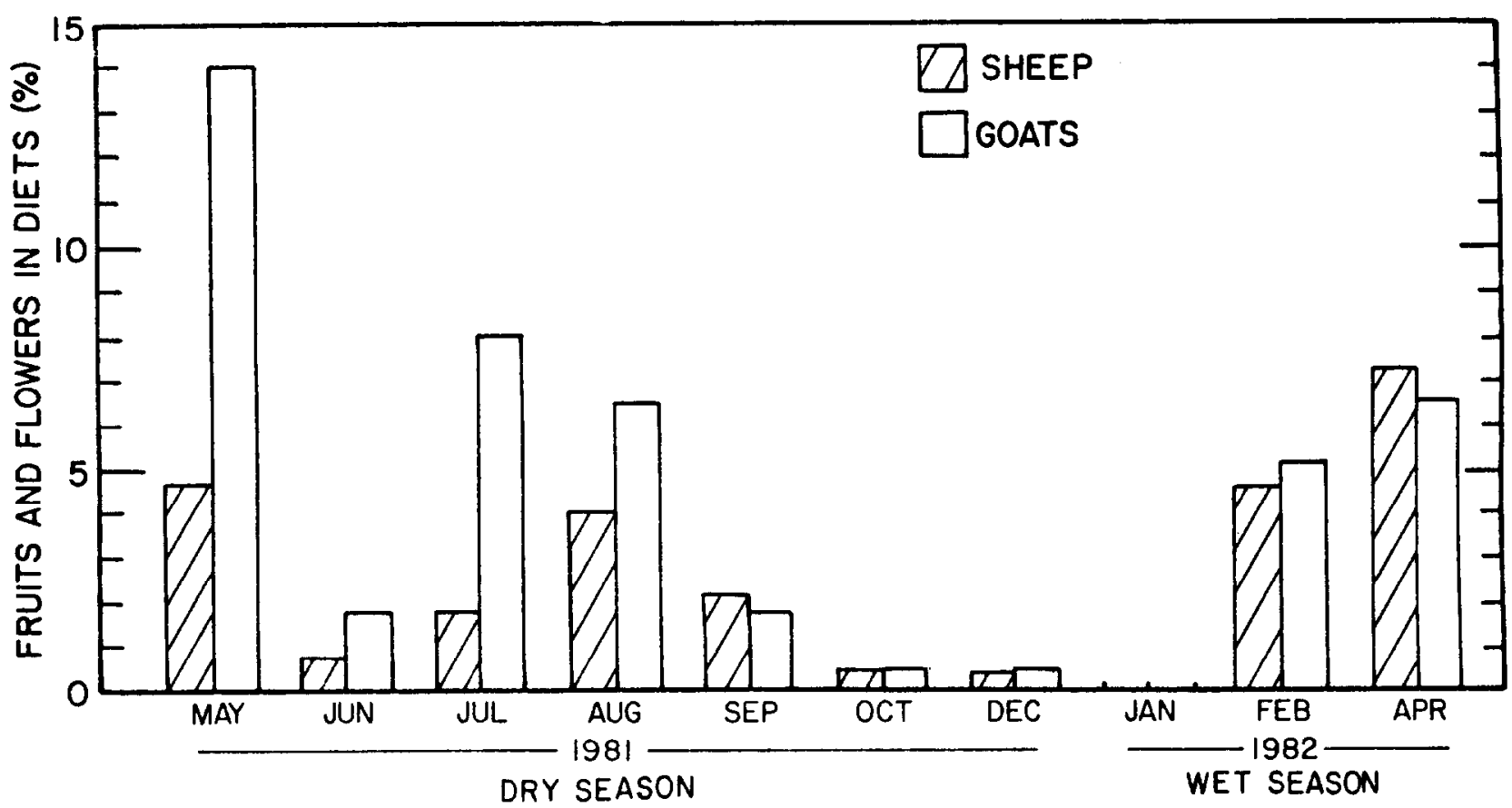

PERIOD

Fig. 2. Quantities (\%) of fruits and flowers in goats' and sheep diets during 10 sampling periods.

sabia', mororo', and marmeleiro), and jitirana were major dietary components. Leaf:stem ratios in these periods were consistently low (Table 1), reflecting large amounts of stem in the diets.

At the onset of the wet season in late December there was a divergence in composition of goats' and sheep diets. During January and February sheep selected large amounts of grass (30-50\%) and forbs (45-55\%). Little browse (2-10\%) was consumed by sheep during these first 2 wet season periods. During April sheep began selecting more browse (55\%) and less forbs and grass.

Goats initially selected browse in January $(>65 \%)$ and then shifted to diets composed of nearly equal parts of browse, forbs, and grass in February. By April goats were selecting more browse and forbs. Grass was utilized very little.

Generally the plant species in the diets of sheep and goats were dissimilar during the wet season (Table 1). Sheep selected for large amounts of annual forbs, annual grasses, and the half-shrub, melosa (Ruellia asperula Lindau). Goats'diets consisted mainly of the tree species sabia' and mororo', annual grasses, annual forbs, and other browse species. Leaf:stem ratios during the wet season (Jan.-Apr.) indicated a significant $(P<0.1)$ difference between goats and sheep in January. Fruits and flowers were important dietary constituents sporadically during the study (Fig. 2).

\section{Discussion}

\section{Dietary Selection}

The degree of dietary overlap between sheep and goats was greatest in the dry season. Available leaf litter was largely pau branco, a tree species both goats and sheep found unacceptable. Discounting pau branco, there was only about $250 \mathrm{~kg} / \mathrm{ha}$ of acceptable forage in the late dry season. Goats and sheep limited their grazing to the same approximate vertical space during the late dry season (Oct.-Dec.) (Pfister et al. 1985). Therefore, this study provided indirect evidence of severe inter-species competition during the dry season. Given the large amount of available forage during the wet season, differences between sheep and goats in partitioning their vertical grazing space, and dietary differences, competition was apparently reduced during the wet season.
Diet studies have typically shown large seasonal variation in the diets of sheep and goats (Malechek and Leinweber 1972, Bryant et al. 1979). This study was no exception. Both sheep and goats demonstrated rapid changes in dietary selections. For example, grass, largely ignored during most of the year, became an important dietary component for goats during February (Table 1) and March (personal observation). Goats were especially attracted to the seedheads. Several other studies have reported the extensive, but highly seasonal, use of grass by goats (Malechek and Leinweber 1972, de Toit 1972, Nge'the and Box 1976, Bryant et al. 1979).

Leaf litter was a major dietary element for both sheep and goats during the dry season. During the late dry season, nearly $100 \%$ of the available forage was leaf litter. The decline in leaf litter biomass from August to October was apparently due to weathering and decomposition, trampling, and consumption by the grazing animals. Wilson et al. (1975) reported that dry leaves were important in goats' diets in Australia.

Fruits and flowers were seasonally important in animals' diets. Malechek (1982) and Malechek and Provenza (1983) have commented that these plant parts may be crucial to animal survival at times of nutritional stress. This may be true even though fruits or flowers represent a very small fraction of the diets, because these parts are often high in nutrients (Schwartz and Said 1981, Everitt and Alaniz 1981). For example, nutritional analysis of jitirana fruits indicated crude protein levels near 30\% in August (Pfister 1983). Goats were especially adapt at prehending these fruits through use of a bipedal stance.

The native animals used in this study were apparently well adapted to the semiarid range conditions of northeast Brazil. Sheep and goats displayed attributes of both browsers and grazers. Van Soest's (1982:7) classification of goats as intermediate browsers, and sheep as grazers appears inappropriate in this area. Van Soest's earlier (1980) classification of goats as forb- or browsepreferring intermediate feeders, and sheep as grass-preferring intermediate feeders more closely resembles the pattern shown in this study.

We found large variability in dietary selectivity within groups of 
sheep and goats during most months, and also seasonally. Other research has also indicated that genotypic variation in dietary selection within the species may be as large as that between species (Bryant et al. 1979; Warren et al. 1981, 1983). Such a selective strategy may be an important adaptive feature in the highly stochastic caatinga environment.

\section{Management Implications}

Slash and burn agriculture for subsistence cropping is widespread in the caatinga zone. Many ranchers feel that clearing the caatinga of trees allows more forage growth. However the longterm benefits of wholesale clearing are dubious. Walker (1979) maintained that trees in semiarid woodlands serve to reduce environmental fluctuations, even though trees produce less green foliage than annual plants. Complete clearing of the caatinga may favor short-term site productivity at the expense of long-term stability (Malechek 1982).

Selective clearing of the dominant tree species, pau branco, is recommended. Pau branco was not acceptable forage to goats and sheep during most of the year. This species coppices readily after cutting, and observations indicate that regrowth is more palatable to livestock than mature foliage. Selective clearing would remove some competition for light and moisture, yet retain sufficient quantity of the desirable trees. This would also provide opportunities for the introduction of more palatable plant species. In addition, this clearing could be done with readily available labor, and sales of the pau branco wood could provide cash benefits to landowners.

Sabia', catingueira, and mororo' should be protected from clearing. Sabia' and mororo' coppice readily after cutting, and sheep and goats severely browse the palatable regrowth, often killing young trees. Catingueira, on the other hand, is relatively unpalatable as green forage, but the dry tree leaves are nutritious and provide the bulk of the late dry season forage. These 3 trees provide wet season forage, but are best reserved as dry season forage.

The leaf litter from desirable trees plays a more important role than simply providing animal fodder. This material protects soil from erosion, especially when the area is most vulnerable at the end of the dry season. The first rains are usually very intense and annual plants give little protective ground cover. Without the tree and leaf litter cover, increased soil erosion is certain (Marinho et al. 1982).

Further research aimed at unravelling many complex plantanimal relationships in the caatinga is needed. The role of some "undesirable" tree species, such as the invader marmeleiro (Croton spp.), needs to be clarified. Considered a weedy species, marmeleiro provided animals forage at a critical time in the dry season during our study. Such information is important for formulation of ecologically sound management objectives, designed to halt the degradation of caatinga rangelands.

Although of limited duration, this study gave no indication that goats were superior to sheep for grazing caatinga vegetation of the type found near Sobral. Similarity of diets during the stressful dry season indicates that the question of goat and sheep survivability will be best addressed by examining nutritional aspects rather than botanical composition of their diets.

\section{Literature Cited}

Bryant, F.C., M.M. Kothmann, and L.B. Merrill. 1979. Diets of sheep, Angora goats, Spanish goats, white-tailed deer under excellent range conditions. J. Range Manage. 32:412-417.

Bryce, G.R., D.T. Scott, and M.W. Carter. 1980. Data analysis in Rummage - a user's guide. Applied Statistics Group. Brigham Young University, Provo.

Devendra, C. 1978. The digestive efficiency of goats. World Rev. Anim Prod. 14:9-22.

Du Toit, P.F. 1972. The goat in a brush-grass community. Proc. Grassl. Soc. Sth. Afr. 7:44-50.

Eiten, G., and R. Goodland. 1979. Ecology and management of semi-arid ecosystems in Brazil. P. 277-301. In: B.H. Walker, ed. Management of semi-arid ecosystems. Elsevier Scientific Publ. Co., Amstcrdam.
Everitt, J.H., and M.A. Alaniz. 1981. Nutrient content of cactus and woody plant fruits eaten by birds and mammals in south Texas. The Southwestern Nat. 26:301-305.

Ferri, M.G. 1980. Vegetacao Brasileira. Edicao da Universidade de Sao Paulo.

Freise, F.W. 1938. The drought region of northeastern Brazil. Geograph. Rev. 28:363-378.

French, M.H. 1970. Observations on the goat. Agricultural Studies No. 80 . FAO, Rome.

Gill, John L. 1978. Design and analysis of experiments in the Animal and Medical Sciences. Vol. 2. The Iowa State University Press, Ames.

Gutierrez, N., A.J. DeBoer, and J. Ubiraci. 1981. Some resource interactions and economic characteristics of sheep and goat producers in the sertao of Ceara state, northeast Brazil: some preliminary survey results. Proc. 1st National Symp. on Tropical Sheep and Goats. EMPBRAPA/CNPq, Fortaleza, Ceara'.

Harker, K.W., D.T. Torell, and G.M. Van Dyne. 1964. Botanical exmination of forage from esophageal fistulas in cattle. J. Anim. Sci. 23:465-469.

Malechek, J.C. 1982. Grazing management of goats in extensive rangeland production systems. In: Proc. 3rd Int. Conf. on Goat Prod. and Disease. Dairy Goat Journal Pub. Co., P.O. Box 1808, Scottsdale, Ariz.

Malechek, J.C., and C.L. Leinweber. 1972. Forage selectivity by goats on lightly and heavily grazed ranges. J. Range Manage. 25:105-111.

Malechek, J.C., and F.D. Provenza. 1983. Feeding behavior and nutrition of goats on rangelands. World Anim. Rev. 47:38-48.

Marinho, H.E., L.V Vale, and A.D. Ramos. 1982. Estudo da erodabilidade de um solo litolico sem cobertura vegetal e sob duas condicoes de pastagem nativa de caatinga. P. 92-94. In: Relatorio Tecnico Anual do Centro National de Pesquisa de Caprinos, 1980-1982, Sobral, Ceara', Brasil.

McCammon-Feldman, B., P.J. Van Soest, P. Horvath, and R.E. McDowell. 1981. Feeding strategy of the goat. Cornell Int. Agr. Mimeo, July.

Ngethe, J.C., and T.W. Box. 1976. Botanical composition of eland and goat diets on an acacia-grassland community in Kenya. J. Range Manage. 29:290-293.

Prister, J.A. 1983. Nutrition and feeding behavior of goats and sheep grazing deciduous shrub-woodland in northeastern Brazil. Ph.D. Diss. Utah State Univ., Logan.

Pfister, J.A., J.S. de Queiroz, R.D. Kirmse, and J.C. Malechek. 1983. Rangelands and small ruminant production in Ceara'state, northeastern Brazil. Rangelands 5:72-76.

Pfister, James A., John C. Malechek, and David F. Balph. 1985. Horizontal stratification of foraging by sheep and goats and its nutritional consequences. Applied Anim. Behav. Sci. (submitted).

Primov, G. 1982. Small Ruminant Production in the Sertao of Ceara, Brazil: A Sociological Analysis. Small Ruminant Collaborative Research Support Program, Publication 6, Department of Rural Sociology, Univ. of Missouri, Columbia.

Schwartz, J.J., and A.N. Said. 1981. Dietary preferences of goats and nutritive value of forage on semi-arid pastures in northern Kenya. $P$. 515-524. In: P. Morand-Fehr, A Bourouze, and M. de Simiane, eds. Nutrition and systems of goat feeding, Proc. Int. Symp., Tours, France. Paris, INRA-ITOVIC.

Trewartha, G.T. 1981. The earth's problem climates. 2nd edition. Univ. of Wisconsin Press, Madison.

Van Dyne, G.M., N.R. Brockington, Z. Szocs, J. Duek, and C.A. Ribic. 1980. Large herbivore subsystem. P. 269-538. In: A.I. Breymeyer and G.M. Van Dyne, eds. Grasslands, systems analysis and man. Int. Biol. Pro. 19. Cambridge Univ. Press, London.

Van Soest, P.J. 1980. Impact of feeding behavior and digestive capacity on nutritional response. Tech. Consultation on Animal Genetics Resources Conserv. and Manage., Rome.

Van Soest, P.J. 1982. Nutritional ecology of the ruminant, O \& B Books, Corvallis, Oren.

Walker, B.H. 1979. Game ranching in Africa. P. 55-81. In: B.H. Walker, ed. Management of semi-arid ecosystems. Elsevier, Amsterdam.

Warren, L.E., D.N. Ueckert, and J.M. Sheldon. 1981. Dietary choices of selective breeds of sheep and goats grazing in west Texas. Sheep and Goat, Wool and Mohair. Texas Agr. Exp. Sta. Res. Rep. PR 3907.

Warren, L.E., D.N. Ueckert, and J.M. Sheldon. 1983. Comparative diets of Rambouillet, Barbado, and Karakul sheep, and Spanish and Angora goats. Abstracts 36th Annual Mtg. Soc, for Range Manage., Albuquerque, N. Mex.

Wilson, A.D., J.H. Leigh, N.L. Hindley, and W.E. Mulham. 1975. Comparison of the diets of goats and sheep on a Causuarina cristataHeterodendrum oleifolium woodland community in western New South Wales. Aust. J. Exp. Agr. Anim. Husb. 15:45-53. 


\section{Anagyrine in Western American Lupines}

A.M. DAVIS AND D.M. STOUT

\section{Abstract}

The teratogenic condition known as 'crooked calf disease' occurs when pregnant cows eat certain lupines with anagyrine concentrations at or above $1.44 \mathrm{~g} \mathrm{~kg}^{-1}$ dry matter between the 40th and 70th day of pregnancy. Five of eight species collected in Oregon and Washington had accessions with anagyrine at or above the hazardous concentrations as determined by gas/liquid chromatography. A total of 14 species of lupine are now shown to contain accessions with potentially hazardous concentrations of anagyrine. Any range/livestock management system that will expose susceptible cattle to anagyrine-bearing lupines could result in serious calf crop losses.

Lupine species are distributed throughout the temperate regions of the world and are particularly rich in western North America. Speciation within the genus is extensive and confusing. Rydberg (1922) developed a list of 80 species in the Rocky Mountains and the adjacent plains, Tidestrom (1925) listed 53 from the Great Basin, and Hitchcock and Cronquist (1976) accepted 23 species in Washington. To further complicate species identification within the genus, Herman (1966) noted that hybridization among the species is a common occurrence.

Lupines have been considered good to poor feed, depending on their toxic principals, season of use, and class of livestock (Herman 1966). They have been shown to be a common source of the apparently teratogenic alkaloid anagyrine (Keeler 1976) and the extent of its occurrence is only partially understood. At least 9 species are reported to contain anagyrine in concentrations high enough to cause crooked calf disease (Davis 1982). The true extent of the teratogenic potential of this genus will not be known until the lupine species and ecotypes are more completely collected and analyzed. This study was undertaken to further the understanding of the distribution of the probable teratogen anagyrine in the native western American lupines.

\section{Materials and Methods}

The collection of native lupines (Tables 1 and 2) represents the native species commonly found in the rangelands of the Pacific Northwest. The procedures for field grown lupines were the same in this experiment as were employed by Davis (1982) and are not repeated here. This collection has been catalogued and entered in the USDA Plant Introduction system and seeds of all accessions that were used in this study are available for further testing, evaluation or breeding at the authors' address.

The accessions reported in Table 2 were grown in plastic greenhouse pots 9 inches in diameter and 9 inches high $(22 \mathrm{~cm} \times 22 \mathrm{~cm})$ containing $2.2 \mathrm{lb}(1 \mathrm{~kg})$ of air-dried soil mix, 1/3 soil, (Tucannon silt loam), 1 / 3 commercial peat, and $1 / 3$ riverbank sand v/v. Each pot received $15 \mathrm{ml}$ of a complete nutrient solution before planting, (Hoagland) and Arnon 1950). Twelve scarified lupine seeds were uniformly disturbed in the pot in 6 evenly distributed locations.

\footnotetext{
Authors are research agronomist, USDA, ARS, WR, and agricultural research technician, Washington State University, Western Regional Plant Introduction Station, Pullman 99164.

This article is a contribution from Agricultural Research Service, U.S. Department of Agriculture, in cooperation with the College of Agriculture Research Center, Washington State University, Pullman 99164. Scientific Paper No. 6627.

Reference samples of previously analyzed lupine tissue, as well as purified extracts of anagyrine were provided by Dr. Richard Keller, USDA Poisonous Plant Labora-

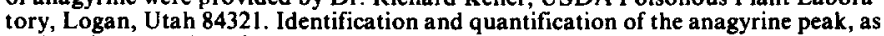
well as the total alkaloids, was based on those samples.

Manuscript accepted 11 June 1985.
}

and 4 pots were seeded to each accession for a total of 156 pots in the experiment. Each pot was thinned to 6 plants per pot as soon as the seedlings were well established. At 6,12 , and 18 weeks after emergence, an additional $15 \mathrm{ml}$ of the same nutrient solution as initially used was injected into the soil of each pot with a repeating syringe. When the plants were 24 weeks old, the tops were cut to ground level. The plants from each pot were analyzed for anagyrine and total alkaloids by the procedures used by Davis (1982). Anagyrine and total alkaloid concentrations reported in Table 2 are the averages of 4 pots, each with 6 plants.

\section{Results and Discussion}

Six of the eight field-grown lupine species sampled contained identifiable amounts of anagyrine (Table 1). Five had concentrations high enough to be potentially teratogenic, i.e., greater than $1.44 \mathrm{~g} \mathrm{~kg}^{-1}$ (Keeler 1976). The presence of anagyrine in toxic amounts was previously reported by Davis (1982) for all species in this trial except the seashore lupine ${ }^{6}$. Lupines contain many alkaloids in addition to anagyrine (Waller and Nowacki 1978). Anagyrine may be considered a minor alkaloid in most species when compared to the concentrations of sparteine, lupinine, and lupanine. These and other lupine alkaloids are responsible for the classic symptoms of lupine poisoning or toxicosis (Anon. 1968). The average highest total alkaloid concentration was found in silvery lupine, with a range of 11.4 to $50.2 \mathrm{~g} \mathrm{~kg}^{-1}$. In contrast, the anagyrine content of spurred lupine, was only $0.1 \mathrm{~g} \mathrm{~kg}^{-1}$ in the 2 collections that had detectable levels, but total alkaloid varied from 8 to $25 \mathrm{~g} \mathrm{~kg}^{-1}$. The dry ground lupine, a low growing, moundlike, almost stemless lupine, was low in total alkaloids with a range of 4.2 to $18 \mathrm{~g} \mathrm{~kg}^{-1}$ and no anagyrine was found. This species is morphologically similar to the prairie lupine, a recognized poisonous species, and is considered by some botanists to be a subspecies of the prairie lupine. Burke's lupine had anagyrine in 3 of the 4 accessions, but only 1 of these was high enough to be potentially teratogenic. Burke's lupine ranked second only to the silvery lupine in total alkaloids.

The tailcup lupine was the only species in which all of the accessions had anagyrine concentrations at or above the minimum teratogenic level of $1.44 \mathrm{~g} \mathrm{~kg}^{-1}$. These concentrations verify the teratogenicity of this species as reported by Keeler (1976). Total alkaloids ranged from $6-12 \mathrm{~g} \mathrm{~kg}^{-1}$ with anagyrine the principal alkaloid in this species, averaging $33.5 \%$ of the total alkaloid content. Other teratogenic lupines were the silky lupine, the velvet lupine and the seashore lupine.

Lupine species collected from Montana, Idaho, California, Oregon, and Washington were grown in the greenhouse and alkaloid levels are presented in Table 2. Eleven species were found to have accessions with anagyrine levels above the critical concentration of $1.44 \mathrm{~g} \mathrm{~kg}^{-1}$. None of the annual species were found to contain anagyrine at teratogenic levels.

The cultivar 'Hederma' (sickle-keeled or pine lupine) is the only developed agronomic cultivar of a native western lupine. Ornamental cultivars have been bred from the Washington lupine, (Kelsey and Dayton 1942) and have been used for green manure in Europe. 'Hederma' has been fed to cattle and sheep with no teratogenic effects (James 1976). Foliage of 'Hederma' has been analyzed by the author and no anagyrine was found, but high concentrations of total alkaloids were present. By comparison 2 of the 3 wild collected accessions of sickle-keeled or pine lupine showed concen- 